\title{
PENGARUH LAYANAN KONSELING KELOMPOK TERHADAP KEMAMPUAN KOMUNIKASI INTERPERSONAL PADA SISWA KELAS VII 3 SMP NEGERI 3 KOTA BENGKULU
}

\author{
Rini Juita, Pudji Hartuti, Arsyadani Mishbahuddin \\ Prodi Bimbingan dan Konseling Fakultas Keguruan dan Ilmu Pendidikan \\ Universitas Bengkulu \\ rinijuita11@gmail.com,pudjihartuti@unib.ac.id, arsyadani@unib.ac.id
}

\begin{abstract}
ABSTRAK
Penelitian ini adalah penelitian eksperimen dengan jenis desain one group pre-test dan posttest, yang dilakukan sebanyak dua kali yaitu sebelum melaksanakan konseling kelompok dan setelah melaksanakan konseling kelompok. Sampel penelitian adalah 10 orang siswa, yang terdiri 8 orang siswa yang memiliki kemampuan komunikasi interpersonal pada kategori rendah, dan dua (2) orang siswa pada kategori sedang. Teknik yang digunakan dalam penelian ini adalah purposive sampling. Pengumpulan data dilakukan menggunakan Skala Likert yaitu skala kemampuan komunikasi interpersonal. Sedangkan teknik analisis data yang digunakan adalah statistik non parametrik dengan rumus Wilcoxon (uji Z), menggunakan SPSS 21. Hasilnya diperoleh 0.001 ( $\mathrm{p}<0.05)$, sehingga dapat ditarik kesimpulan bahwa ada pengaruh layanan konseling kelompok terhadap peningkatan kemampuan komunikasi interpersonal siswa SMP Negeri 3 Kota Bengkulu.
\end{abstract}

Kata kunci: kemampuan komunikasi interpersonal, layanan konseling kelompok

\section{INFLUENCE OF COUNSELING COUNSELING SERVICES TO INTERPERSONAL COMMUNICATION CAPABILITIES IN STUDENT CLASS VII 3 SMP NEGERI 3 BENGKULU CITY}

\begin{abstract}
This research is an experimental research with one group type pre-test and post-test, which is done twice before doing group counseling and after carrying out group counseling. The sample was 10 students, consisting of 8 students with interpersonal communication skills in the low category, and two (2) students in the medium category. The technique used in this research is purposive sampling. Data collection is done using Likert Scale is the scale of interpersonal communication skills. While the data analysis technique used is non parametric statistic with Wilcoxon formula ( $Z$ test), using SPSS 21. The results obtained 0.001 ( $p<0.05$ ), so it can be concluded that there is influence of group counseling services on improving interpersonal communication skills of students of SMP Negeri 3 Kota Bengkulu.
\end{abstract}

Keywords: interpersonal communication skills, group counseling services 


\section{Pendahuluan}

Manusia adalah makhluk sosial. Salah satu yang membuktikan bahwa manusia sebagai makhluk sosial adalah perilaku komunikasi antar-manusia. Manusia tidak bisa hidup sendiri, pasti memerlukan orang lain. Sejak dilahirkan hingga tiada, manusia cenderung memerlukan bantuan dari orang lain (yang tidak hanya terbatas pada keluarga, tetapi juga tetangga dan teman). Kecenderungan ini dapat dilihat dalam kehidupan sehari-hari yang menunjukkan fakta bahwa semua kegiatan yang dilakukan manusia selalu berhubungan dengan orang lain, baik individu maupun sekelompok orang.

Pada saat usia memasuki usia 13-17 tahun, anak memasuki usia remaja (Hurlock, 2006:206). Secara psikologis, masa remaja adalah usia individu berintegrasi dengan masyarakat dewasa. Pada usia remaja diharapkan seseorang tidak lagi merasa di bawah tingkat orangorang yang lebih tua melainkan berada dalam tingkatan yang sama, sekurangkurangnya dalam masalah hak (Hurlock, 2006:206). Periode ini bertepatan dengan anak memasuki usia Sekolah Menengah Pertama (SMP).

Salah satu tugas perkembangan yang harus dipenuhi oleh anak pada masa sekolah adalah belajar bergaul dengan kelompok teman sebaya (Havigurst dalam Susanti, 2010:145), nantinya mereka akan memulai mempunyai kemampuan di antaranya berinisiatif, bersikap asertif, membuka diri, memberikan dukungan emosional, dan mengatasi konflik. Untuk melakukan semua hal itu remaja harus mempunyai kemampuan interpersonal karena pada pada usia ini seharusnya anak sudah dapat mengembangkan kemampuan interpesonalnya, minimal mempunyai kemampuan untuk bersikap terbuka.

Berdasarkan hasil pengamatan peneliti saat melaksanakan magang 3 pada tanggal 03 Oktober- 03 Desember 2016 di SMP Negeri 3 Kota Bengkulu ada remaja pada usia ini belum dapat menunjukkan perkembangan interpersonaln ya, dia sulit terbuka, belum bisa mengemukakan pendapat dan belum bisa berinteraksi dengan baik yang seharusnya sudah berjalan dengan baik. (Baron \& Byrne, dalam Susanti, Siswanti, Widodo, 2010:146) menjelaskan bahwa individu dengan kompetensi interpersonal rendah, kurang mampu untuk memulai hubungan interpersonal meskipun sudah melakukan hubungan interpersonal tetapi tidak mampu mengembangkan hubungan tersebut menjadi hubungan yang lebih akrab dan menyenangkan. 
Menurut McDavid \& Harrari (dalam Maulana \& Gumelar G, 2013:75) komunikasi interpersonal yaitu suatu proses komunikasi yang ber-setting pada objekobjek social untuk mengetahui pemaknaan suatu stimulus yang berupa informasi atau pesan. Sedangkan menurut De Vito (dalam Maulana \& Gumelar, 2013:75) komunikasi interpersonal adalah penyampaian pesan oleh satu orang dan penerimaan oleh orang lain atau sekelompok orang, dengan berbagai dampaknya dan dengan peluang untuk memberikan umpan balik.

Menurut Dayakisni \& Hudaniah dalam Susanti, Siswanti, Widodo (2010:146), kompetensi interpersonal adalah suatu kemampuan untuk menjalin dan mempertahankan hubungan dalam jangka waktu lama. Kemampuan seseorang, termasuk kemampuan komunikasi, tidak hanya ditentukan oleh masalah fisik \& keterampilan saja, tetapi juga dipengaruhi oleh kepercayaan diri. (Taylor, dkk dalam Siska, Sudarjo, Purnamaningsih 2003:68), mengungkapkan bahwa komunikasi interpersonal terjadi ketika seseorang berkomunikasi secara langsung dengan orang lain dalam situasi one-to-one atau dalam kelompok kelompok kecil. Berbeda dengan pendapat Maulana \& Gumelar (2013: 75) yang menjelaskan komunikasi interpersonal adalah komunikasi antara komunikator dengan komunikan, komunikasi antara orang-orang secara tatap muka, yang memungkinkan setiap pesertanya menangkap reaksi orang lain secara lansung baik secara verbal atau nonverbal. Dari definisi di atas komunikasi interpersonal adalah suatu proses komunikasi untuk membuka diri dan mempererat hubungan dengan orang lain atau sekelompok orang dengan tujuan untuk mendapatkan harga diri dan kehormatan.

Kelompok adalah suatu unit yang terdapat beberapa individu yang mempunyai kemampuan untuk berbuat dengan kesatuannya dengan cara dan atas dasar kesatuan persepsi (Harnert Smith dalam Mashudi Farid, 2011: 247). Kelompok merupakan kumpulan dari orang-orang yang mengadakan interaksi dengan sesamanya. Untuk membantu siswa meningkatkan kemampuan interpersonalnya, kegiatan konseling kelompok dapat digunakan menjadi kegiatan untuk mengembangkan kemampuan di antaranya berinisiatif, bersikap asertif, membuka diri, memberikan dukungan emosional, dan mengatasi konflik.

Berdasarkan hasil observasi pada saat Magang 3 di SMP Negeri 3 Kota Bengkulu Tahun ajaran 2016/2017, terhadap siswa kelas VII 3 dan layanan klasikal yang 
peneliti lakukan, siswa yang memiliki masalah komunikasi interpersonal atau antar-pribadi; terdapat siswa yang kurang dapat mengemukakan pendapat ketika diminta untuk berbicara di depan kelas atau pada kegiatan diskusi kelompok dilakukan. Selain itu, ada siswa yang masih terlihat gugup dan takut untuk bertanya apabila praktikan memberikan kesempatan untuk bertanya, Siswa tersebut pada akhirnya juga mengalami kesulitan dalam komunikasi interpersonal pada saat mengikuti pelajaran. Layanan konseling kelompok adalah suatu layanan yang digunakan untuk membantu siswa menyelesaikan masalah yang mereka alami dalam suasana kelompok dan masalah yang diselesaikan adalah yang bersifat khusus. Masalah tersebut menunjukkan komunikasi interpersonal rendah dikelompokkan dalam masalah bimbingan pribadi-sosial, pembahasan pada ranah ini adalah masalah yang bersifat khusus.

Konseling Kelompok adalah layanan yang membantu peserta didik dalam pembahasan dan pengentasan masalah pribadi melalui dinamika kelompok (Mashudi Farid, 2011: 248). Sedangkan Gadza, dkk (dalam Mardiah, 2011:26) menjelaskan bahwa layanan konseling kelompok adalah suatu proses antara pribadi yang terpusat pada pribadi yang dinamis, terpusat pada pemikiran dan perilaku yang sadar dan melibatkan fungsifungsi seperti berorientasi pada kenyataan, saling mempercayai, saling pengertian, saling menerima, dan saling mendukung. Dari beberapa penjelasan tersebut disimpulkan bahwa konseling kelompok adalah suatu kegiatan pemberian bantuan kepada sekelompok orang, untuk menumbuhkan rasa percaya diri, saling mendukung, menerima kenyataan dan mampu memperbaiki diri mereka masingmasing.

\section{Metode Penelitian}

Metode penelitian ini digunakan dalam penelitian eksperimen dengan jenis penelitian yang diambil adalah satu kelompok Pretes-postes (the one Group Pretest-posttest) desain ini termasuk di dalam desain pra-eksperimental (preeksperimental designs). Selanjutnya penelitian ini menggunakan teknik porpusive sampling, dengan perlakuan diberikan terhadap subjek penelitian adalah layanan konseling kelompok. Perlakuan diberikan sebanyak empat kali pertemuan. Pengkuran yang digunakan adalah instrumen yang sama yaitu angket skala Likert kemampuan komunikasi interpersonal. 


\section{Hasil Dan Pembahasan}

Berdasarkan hasil pengolahan data disimpulkan bahwa terjadi peningkatan kemampuan komunikasi interpersonal pada subjek yang berjumlah 10 orang. Hal ini Tabel 1.

Peningkatan Skor terlihat dari hasil post-test setelah diberi layanan konseling kelompok. Untuk lebih jelasnya dapat dilihat pada Tabel 1 .

\section{No Responden Skor pre-test kategori Skor post-test Kategori Skor peningkatan}

\begin{tabular}{lllccll}
\hline 1 & AVP & 74 & Kurang baik & 97 & Sangat Baik & 23 \\
\hline 2 & FNI & 74 & Kurang baik & 97 & Sangat Baik & 23 \\
\hline 3 & FHT & 75 & Kurang baik & 96 & Sangat Baik & 21 \\
\hline 4 & FI & 79 & Sedang & 93 & Sangat Baik & 14 \\
\hline 5 & JAA & 79 & Sedang & 96 & Sangat Baik & 17 \\
\hline 6 & LH & 75 & Kurang baik & 98 & Sangat Baik & 23 \\
\hline 7 & MPA & 70 & Kurang baik & 95 & Sangat Baik & 25 \\
\hline 8 & MGF & 74 & Kurang baik & 95 & Sangat Baik & 21 \\
\hline 9 & OT & 73 & Kurang baik & 95 & Sangat Baik & 22 \\
\hline 10 & RAH & 76 & Kurang baik & 97 & Sangat Baik & 21 \\
\hline JUMLAH & 749 & & 959 & & 210 \\
\hline RATA-RATA & 74,9 & & & & 21 \\
\hline
\end{tabular}

Hasil pengambilan data awal (pretest) sesuai dengan diperoleh siswa yang dikategorikan memiliki komunikasi interpesonal rendah 8 orang, dan 2 orang siswa memiliki komunikasi interpersonal sedang, dan tidak ada siswa yang memiliki komunikasi interpersonal sangat rendah, tinggi dan komunikasi interpersonal yang sangat tinggi. Sampel yang termasuk dalam kategori rendah dan sedang keterampilan Tabel 2.

Hasil Uji Z (Wilcoxon Signed Ranks Test) komunikasi interpersonalnya diberi treatment berupa konseling kelompok. Adanya peningkatan kemampuan komunikasi interpersonal siswa yang semula berada pada kategori sedang, dan rendah, berubah menjadi 10 orang siswa berada pada kategori sangat tinggi. Dengan demikian persentasenya sebesar 100\% dengan interval (>92). 


\begin{tabular}{cc}
\hline Nilai Z & $-2.818^{\mathrm{b}}$ \\
\hline $\begin{array}{c}\text { Taraf } \\
\text { Signifikansi } \\
\text { (Sig-2 tailed) }\end{array}$ & $0.005(\mathrm{p}<0.05)$ \\
\hline Keterangan & $\mathrm{Ha}$ (diterima) dan $\mathrm{H} 0$ \\
& (ditolak) \\
\hline
\end{tabular}

Berdasarkan uji tersebut, nilai $\mathrm{Z}$ adalah $2.818^{\mathrm{b}}$ dan pada taraf signifikansinya adalah 0.005. Dengan demikian Ha (diterima) dan H0 (ditolak). Artinya ada pengaruh layanan konseling kelompok secara signifikan untuk meningkatkan kemampuan komunikasi Tabel 3.

Perbedaan mean pre-test dan post-tes interpersonal siswa kelas VII 3 SMP Negeri 3 Kota Bengkulu. Hasil uji $\mathrm{Z}$ negative($2.818^{\text {b }}$ ) artinya ada pengaruh layanan konseling kelompok untuk meningkatkan kemampuan komunikasi interpersonal.

\begin{tabular}{lll}
\hline & Mean & Peningkatan \\
\cline { 1 - 2 } Pre-test & 74 & \\
\cline { 1 - 2 } Post-test & 95 & 21 \\
\hline
\end{tabular}

Dapat dilihat bahwa mean pre-test 74 dan mean post-test 95. Artinya setelah dilakukan treatment terjadi peningkatan mean Kemampuan Komunikasi Interpersonal siswa sebesar 21. Oleh karena itu dapat disimpulkan bahwa ada pengaruh yang signifikan layanan konseling kelompok untuk meningkatkan kemampuan komunikasi interpersonal efektif sesuai dilakukan di SMP Negeri 3 Kota Bengkulu.

Hasil analisis data deskriptif pre-test dari 10 siswa menunjukkan kemampuan komunikasi interpersonalnya berada pada taraf rendah dan sedang. Siswa yang dijadikan sampel dalam penelitian ini merupakan gambaran kecil dari rendahnya kemampuan komunikasi interpersonal siswa dari jumlah siswa keseluruhan di sekolah yang berjumlah 36 orang siswa.

Sebelum diberikan layanan konseling kelompok, sampel diambil berdasarkan dari hasil angket pretest yang diberikan kepada 36 orang sampel kelas VII 3 SMP Negeri 3 Kota Bengkulu. Dari hasil angket tersebut terdapat 10 orang siswa dengan kemampuan komunikasi interpersonal yang tergolong rendah dan sedang. Siswa yang tergolong pada tingkat komunikasi 
interpersonal rendah pada skor interval 64 77 terdiri dari 8 orang siswa yaitu AVP, FNI, FHT, LH, MPA, M.GF, OT dan RAH. Sedangkan siswa yang tergolong dalam komunikasi interpersonal sedang terdiri dari 2 siswa yaitu FI dan JAA. Sebelum treatment diberikan, peneliti melakukan observasi terlebih dahulu mengenai kemampuan komunikasi interpersonal siswa.

Jadi dapat disimpulkan bahwa permasalahan yang terjadi pada 10 orang siswa kelas VII 3 SMP Negeri 3 Kota Bengkulu tersebut karena masih kurangnya perilaku yang mendukung kemampuan komunikasi interpersonal seperti kurangnya sikap terbuka, toleransi, menghargai orang lain, kesempatan, sikap mendukung dan bertahan, kepemilikan informasi, kepercayaan, keakraban, respon, dan emosional rendah sehingga siswa tersebut tingkat kemampuan komunikasi interpersonalnya rendah.

Setelah diberi layanan konseling kelompok, terjadi peningkatan skor kemampuan komunikasi interpersonal siswa. Hal ini terlihat dari hasil post-test yang telah diberikan, yaitu dari 10 orang anggota kelompok yang sebelumnya masih tergolong pada tarap Kemampuan Komunikasi Interpersonalnya rendah ada 8 orang siswa, dua (2) orang siswa menunjukan kemampuan komunikasi interpersonalnya sedang menjadi 10 orang siswa dengan kemampuan komunikasi interpersonalnya sangat tinggi.

Perubahan skor tersebut karena dalam konseling kelompok dibahas berbagai topik tugas yang berkaitan dengan kemampuan komunikasi interpersonal, treatment dilakukan peneliti sebanyak lima kali pertemuan dengan alokasi waktu 45 menit pada setiap pertemuan. Topik-topik tugas yang diberikan oleh peneliti dalam konseling kelompok dapat mendorong pengembangan perasaan, pikiran, reaksi tubuh, dan tingkah laku yang efektif bagi anggota konseling kelompok, sehingga anggota kelompok dapat melakukan pendekatan personal secara berkelanjutan yang berisi pemberian informasi.

Selama 5 kali pertemuan yang sudah dilakukan, anggota kelompok semakin akrab dan terbuka untuk berbagi cerita, berani mengemukakan pendapat, mau berbagi pengalaman dan informasi sehingga setiap pertemuan terjadi peningkatan atau perubahan kemampuan komunikasi. Berbeda dengan pertemuan pertama, siswa masih sangat tertutup dan pendiam. Pada saat siswa mengisi post-test, siswa sudah lebih memahami diri sendiri dan memahami bagaimana menjadi pribadi yang baik serta memahami bagaimana cara meningkatkan 
kemampuan komunikasi interpersonal. Di antaranya bagaimana berteman dengan baik, menerima pendapat, memberikan pendapat, cara untuk bergabung dalam suatu kelompok atau dengan orang lain, dan berteman baik dengan semua orang. Dari hasil post-test Skala Kemampuan Komunikasi Interpersonal yang diberikan kepada sepuluh orang siswa, dapat disimpulkan bahwa setelah diberikan layanan konseling kelompok menunjukkan kemampuan komunikasi interpersonal mereka mengalami peningkatan

Kegiatan konseling kelompok dapat membuat para siswa secara langsung memahami kemampuan komunikasi interpersonalnya, sehingga mereka mengerti dan memahami bagaimana cara berkomunikasi dengan baik. Kegiatan konseling kelompok ini merupakan wahana pengembangan diri dalam mengembangkan kemampuan diri dan berkomunikasi secara terbuka, serta memberikan kesempatan kepada anggota untuk dapat mengemukakan pendapat masing-masing mengenai bagaimana cara mereka untuk meningkatkan kemampuan komunikasi baik berupa perilaku mampu apa yang dapat mereka lakukan dalam kehidupan seharihari.

Hasil uji hipotesis yang telah dilakukan menunjukkan signifikansi 0.001
$<0.05$. Berdasarkan kriteria penerimaan atau penolakan hipotesis, Ho ditolak dan $\mathrm{Ha}$ diterima maka, dapat disimpulkan bahwa ada pengaruh yang signifikan kemampuan komunikasi interpersonal siswa kelas VII 3 di SMP Negeri 3 Kota Bengkulu sesudah diberi layanan konseling kelompok.

\section{Kesimpulan}

Kemampuan dalam komunikasi interpersonal siswa kelas VII 3 sebelum diberikan layanan konseling kelompok dari 36 orang siswa di kelas didapat 10 orang siswa, yang dikategorikan 8 orang kemampuan komunikasi interpersonal yang kurang baik dan 2 orang dengan kategor sedang. Setelah diberikan layanan konseling kelompok, dari 10 orang siswa terdapat 8 orang memiliki kemampuan komunikasi interpersonal kurang baik, dan 2 orang memiliki kemampuan komunikasi interpersonal sedang menjadi 10 siswa orang yang memiliki kemampuan komunikasi interpersonal sangat baik.

Terdapat pengaruh dari treatment (perlakuan) menggunakan layanan konseling kelompok/ perlakuan kemampuan komunikasi interpersonal siswa kelas VII 3 SMP Negeri 3 Kota Bengkulu. Hal ini dapat dibuktikan dari hasil analisis data yang menyebutkan bahwa Ho ditolak yang berarti terdapat 
peningkatan kemampuan komunikasi

interpersonal siswa setelah diberikan

layanan konseling kelompok.

\section{DAFTAR PUSTAKA}

Hurlok, Elizabeth B. (2006). Psikologi Perkembangan. Jakarta: Erlagga.

Mashudi, farid. (2011). Psikologi Konseling. Yogyakarta: IRCiSoD,

Mardiah. (2011). "Pengaruh Layanan Konseling Kelompok terhadap Disiplin Belajar Siswa di SMA Negeri 1 Antinggola Kabupaten Gorontalo Utara”, Jurnal Penelitian dan Pendidikan. Volume 8, No 1.

Maulana Herdiyan; Gumelar Gumgum. (2013). Psikologi Komunikasi dan Persuasi. Jakarta: Permata Media.

Siska; Sudarjo; Purnamaningsih, Hayu E. (2003). "Kepercayaan Diri dan kecemasan komunikasi Interpersonal Pada Mahasiswa", Jurnal Psikologi. No. 2, 67-71.

Susanti, Fitria; Siswati; Widodo., Budi P. (2010). "Pengaruh Permainan Tradisional Terhadap Kompetensi Interpersonal Dengan Teman Sebaya Pada Siswa SD”, Jurnal Psikologi Undip, Vol 8, No 2. 